\title{
The circulation of the lower Capibaribe Estuary (Brazil) and its implications for the transport of scalars
}

\author{
Carlos Augusto França Schettini ${ }^{1 *}$, Josineide B. de Miranda ${ }^{1}$, Arnoldo Valle-Levinson ${ }^{2}$, Eliane C. \\ Truccolo ${ }^{I}$, Ernesto C. Domingues ${ }^{l}$
}

\author{
${ }^{1}$ Universidade Federal de Pernambuco. \\ (Departamento de Oceanografia - Av. Prof. Moraes Rego, 1235 - Cidade Universitária, Recife - PE - CEP: 50670-901) \\ ${ }^{2}$ University of Florida. \\ (Civil and Coastal Engineering Department, 365 Weil Hall, PO Box 116580, Gainesville, FL, 32611)
}

*Corresponding author: guto.schettini@gmail.com

\begin{abstract}
The Capibaribe Estuary is a water body that crosses the Recife Metropolitan Area (RMA), one of the largest population centers in Brazil, and causes large pollutant loads and poor water quality. The fresh water inflow of wastewater from the RMA can account for three times the volume of the river discharge during the low discharge period. This article assesses the hydrodynamics and potential transport of particulate and dissolved scalars in this estuary. A field experiment was conducted to record the water level, current velocity, salinity, temperature and suspended particulate matter (SPM) contents during a full semi-diurnal tidal cycle. This experiment was performed during low river discharge and spring tide conditions. The estuary showed a partially mixed circulation pattern. The residual transport of water and salt were up estuary, while the SPM residual transport was down estuary. The former were understood as the effect of the residual circulation around the islands, while the latter was interpreted as a morphological factor inducing greater resuspension during the ebb, despite the symmetrical ebb and flood currents. This mechanism may transport SPM to the inner shelf, even under tide-dominated conditions when the opposite would be expected.
\end{abstract}

Descriptors: Hydrodynamics, Hydrology, Water quality, Salinity, Suspended particulate matter.

\section{RESUMO}

O estuário do Rio Capibaribe é um corpo de água que atravessa a Região Metropolitana de Recife (RMR), um dos maiores centros populacionais do Brasil, o que causa grande quantidade de carga de poluentes e baixa qualidade da água. A entrada de água doce a partir das águas residuais da RMR pode contabilizar mais de três vezes a contribuição fluvial durante o período de baixa descarga. Este artigo investiga a hidrodinâmica e o potencial transporte de escalares particulados e dissolvidos neste estuário. Um experimento de campo foi realizado para registrar nível da água, velocidade de corrente, salinidade, temperatura e material particulado em suspensão (MPS) durante um ciclo de maré semidiurno completo. O experimento foi realizado em condições de baixa descarga e em condições de maré de sizígia. O estuário apresentou padrão de circulação parcialmente estratificado. O transporte residual de água e sal foi estuário acima, enquanto que o transporte residual de MPS foi estuário abaixo. Os primeiros são entendidos como o efeito da complexa circulação ao redor das ilhas que formam o baixo estuário, enquanto que o último foi interpretado como devido a efeitos morfológicos que induzem à ressuspensão durante a vazante, a despeito da simetria entre correntes de enchente e vazante. Este mecanismo pode produzir transporte para a plataforma adjacente, mesmo durante períodos dominados pela maré, quando o oposto seria esperado.

Descritores: Hidrodinâmica, Hidrologia, Qualidade da água, Salinidade, Material particulado em suspensão. 


\section{INTRODUCTION}

Estuaries are coastal water bodies that determine most material fluxes between the continent and the ocean. The interactions between the fluvial and marine waters inside an estuarine basin generally produce accentuated environmental gradients. These gradients vary in time and space in response to the estuary's flow (MIRANDA et al., 2002). The estuary's hydrodynamics are driven by tides and river discharge and are constrained by the estuarine morphology, which together control the material budgets of sediments, nutrients and other environmentally relevant scalars, especially pollutants.

The hinterlands of most estuaries were/are favorable to human development, and many of the largest coastal cities around the world (e.g., London, New York, Rio de Janeiro and many others) lie on the banks of estuaries. However, social and economic growth is followed by undesirable effects, such as an increase in the volume of untreated domestic and industrial effluents. Generally, the growth of metropolitan areas is haphazard, which is the primary cause of increases in domestic effluents and changes to the environment. Industries and harbors, which are typically located within large metropolitan areas, are also significant sources of contaminants (CASTRO et al., 2007; MACEDO et al., 2007).

The competition between tides and river discharge in estuarine basins determines the hydrodynamic characteristics of estuaries, influences the way the fresh and salt-water mix and affects the net transport of scalars. Understanding the main hydrodynamic characteristics of an estuary will provide insight into whether a given system is an exporter or importer (trap) of materials, such as suspended particulate matter (SPM). Estuarine SPM consists mainly of inorganic clay (cohesive) and silt/ fine sand (non-cohesive) particles and of allochthonous or autochthonous organic matter (primary productivity). Organic matter usually accounts for only a small fraction of SPM. The main sources of SPM in estuaries are tributary rivers. However, adjacent shelves and waterbed exchanges can also contribute to SPM. The relative contributions of each source are highly variable as a function of geomorphology, climate, oceanography, land use, and many other factors.

The clay portion of SPM is particularly important for assessing environmental quality because clay particles are electrically charged and capable of absorbing most pollutants. A good knowledge of SPM dynamics is a robust proxy for pollutant dynamics (DYER, 1997). Although SPM dynamics are intrinsically related to hydrodynamics (e.g. SCHETTINI, 2002), it is not possible to understand the former without a comprehensive understanding of the latter.

The Capibaribe Estuary (Figure 1) is one of the most important Brazilian coastal water bodies due to its historical significance (CHACON, 1959) and because it crosses one of the most densely populated coastal areas in Brazil, the Recife Metropolitan Region (RMR). Similarly to other large Brazilian metropolitan areas, development in the RMR was poorly planned, which resulted in poor environmental quality. This estuary has been receiving closer attention recently by virtue of several interdisciplinary assessments regarding its functioning, though unfortunately there is very little information on its physical aspects. Despite its importance, the circulation, mixing characteristics and main transport mechanisms in the estuary remain unknown. With a view to providing a first step towards filling this gap, this paper presents a first hydrodynamic assessment of the estuary and a comprehensive description of its physical setting, as well as a review of previous studies. Furthermore, this paper presents an assessment of the potential roles of local hydrodynamics in scalar transport in the lower estuary and its effects on the environmental quality. The hydrological regime of the Capibaribe River is also described.

\section{PHySICAL SETTING}

The Capibaribe River Estuary is centrally located on the coast of Pernambuco State. This estuary is formed by the lower stretch of the Capibaribe River, including the Pina Sound, and receives contributions from the Beberibe, Jordão, Pina and Tejipió streams (Figure 1). The estuary crosses the RMR, which is the largest urban center in Northeastern Brazil with a population of 3,700,000 (IBGE 2010). The RMR encompasses 14 municipalities (the largest of these municipalities are Recife, Jaboatão dos Guararapes and Olinda), which all drain directly into the estuary. Recife alone has a population of 1,900,000 and is the third most densely populated city in Brazil, after São Paulo and Rio de Janeiro.

The main estuary is nearly $25 \mathrm{~km}$ long, approximately $50 \mathrm{~m}$ wide at the head, and $200 \mathrm{~m}$ wide near the mouth, with a total area about of $10 \mathrm{~km}^{2}$. A bathymetric chart is only available for the lower stretch because of the location of Recife Port, where the depths range from -12 to -8 $\mathrm{m}$ due to dredging. The upstream bathymetry that was 


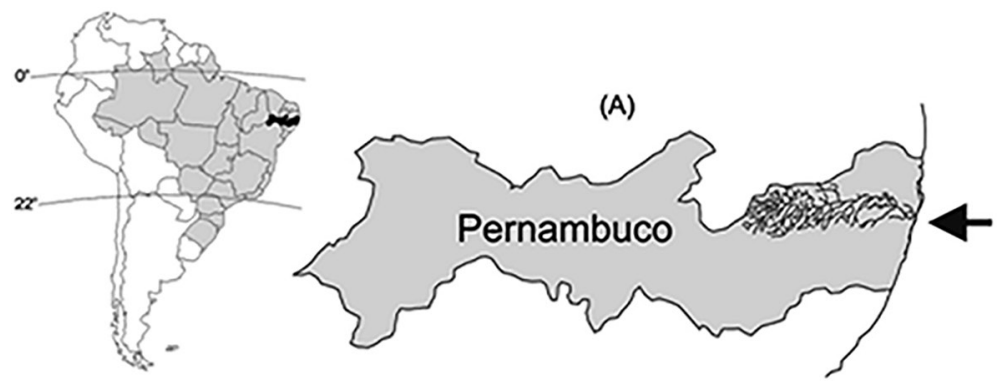

(B)

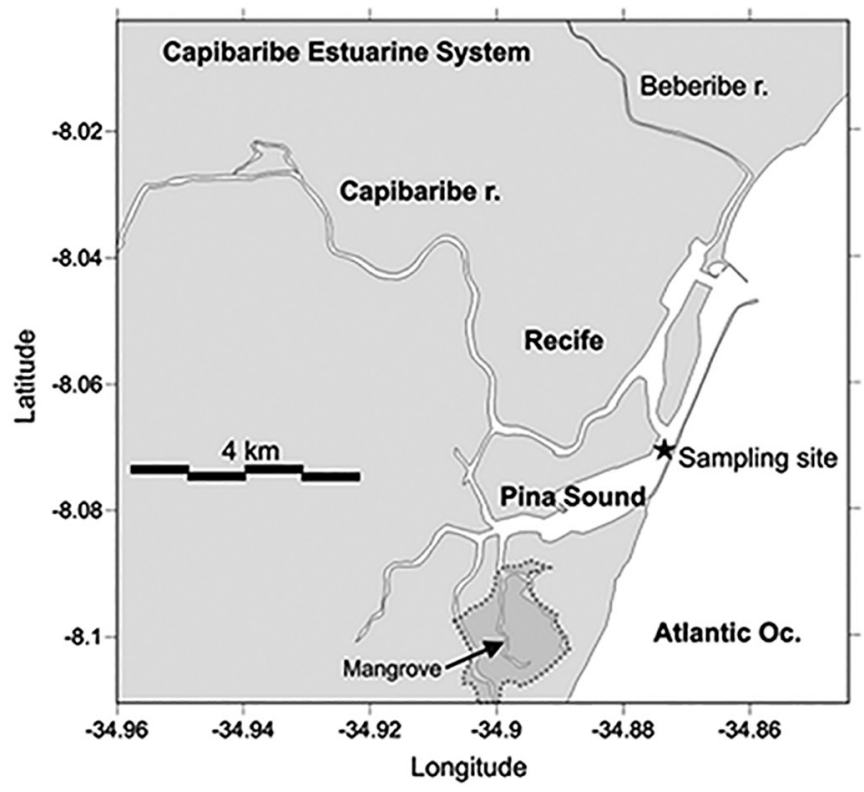

Figure 1. Map of the study area. (A) Pernambuco State and the location of the Capibaribe River drainage system and estuary mouth (arrow). (B) The lower Capibaribe Estuarine System and the sampling site (star).

determined from opportunity soundings varies from -5 to $-3 \mathrm{~m}$ along the main channel. The Pina Sound, a shallow water body that is nearly $3 \mathrm{~km}$ long, $500 \mathrm{~m}$ wide and covers an area of approximately $2 \mathrm{~km}^{2}$, runs roughly parallel to the estuary (FEITOSA et al., 1999). Most of the central portion of the Pina sound is shallow and its bed emerges during the low spring tides. The collection of shellfish by members of the local community is common in the area (SOUZA et al., 2007). Most of the original mangrove areas have been reclaimed and urbanized. Today, mangroves occupy a narrow fringe along the estuary's banks $(<10$ $m$ wide) and within the innermost area of the Pina Sound. The innermost area of the Pina Sound occupies an area of $2.5 \mathrm{~km}^{2}$ and is an area of social/environmental conflict (MOTTA SOBRINHO; ANDRADE, 2009).

The Capibaribe River drainage basin has an area of $7,500 \mathrm{~km}^{2}$ and is approximately $200 \mathrm{~km}$ long and $40 \mathrm{~km}$ wide. In its lower reaches, the basin funnels toward the estuary (Figure 1A). A strong zonal climatic gradient exists, with a warm wet climate with 1 to 2 dry months at the coast to a semiarid climate with 7 to 8 dry months in the inland areas (IBGE, 2010). Nearly 3/4 of the drainage basin has a semiarid climate while only the lowest quarter is characterized by a wet climate. The annual mean temperature in Recife is $25.5^{\circ} \mathrm{C}$ and ranges from 23.9 to 26.6 in August and February, respectively. The temperature decreases by about $2{ }^{\circ} \mathrm{C} 100 \mathrm{~km}$ inland, at Surubim, where the climate is semi-arid. The annual mean precipitation rate is 2,450 and $750 \mathrm{~mm} /$ year at the coast and inland, respectively (RAMOS et al., 2009), while the evapotranspiration rate is $1500 \mathrm{~mm} /$ year, nearly the same at both sites (SRH-PE, 2010). Figure 2 shows the monthly annual variations in the precipitation and evapotranspiration at these two sites. The rainy period is concentrated between March and July and shows greater inter annual variability because it is strongly affected 


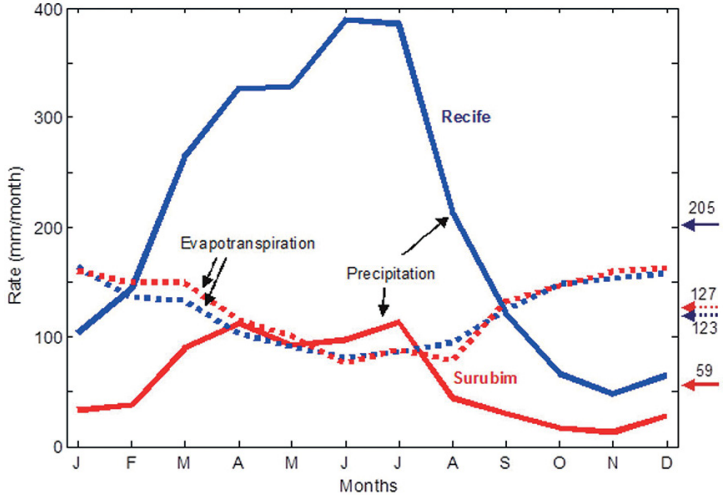

Figure 2. Normal values of monthly precipitation (full lines; from RAMOS et al., 2009) and evapotranspiration (dashed lines; from SRH-PE, 2010) at Recife (blue) and Surubim (red). The arrows on the right side of the figure indicate the annual mean values.

by the El Niño-Southern Oscillation (ANDREOLI; KAYANO, 2007; OLIVEIRA et al., 2011).

The climatic conditions determine relatively low river discharge. This discharge has been monitored daily since the 1970s, and the resulting data are available from the national Brazilian Water Agency (ANA) for the São Lourenço da Mata gauge station (ANA\#39187800). This station is located nearly $35 \mathrm{~km}$ upstream from the mouth of the river (or nearly $10 \mathrm{~km}$ upstream from the head of the estuary) and accounts for $97 \%$ of the total drainage. Figure $3 \mathrm{~A}$ shows the daily time series of the river discharge for the period of 1990 to 2008, which represents the longest periods without data gaps and represents the river discharge pattern well. A strong seasonal pattern can be observed with relatively high inter-annual variability (e.g., in the years 1990, 1998 and 2006). The droughts of 1993, 1998 and 1999 are related to strong El Niño conditions. The average river discharge for the period shown in Figure $3 \mathrm{~A}$ is $11 \mathrm{~m}^{3} / \mathrm{s}$, with a maximum of $1,125 \mathrm{~m}^{3} / \mathrm{s}$. The seasonal discharge pattern is shown in Figure 3B. The periods with the greatest river discharge do not strictly follow the precipitation regime (Figure 2) and occur in June and July. The driest period occurs from October to January. Figure $3 \mathrm{C}$ shows the flow duration curve, which indicates that the river discharge is approximately $2 \mathrm{~m}^{3} / \mathrm{s}$ or less for $50 \%$ of the time, and exceeds $20 \mathrm{~m}^{3} / \mathrm{s}$ for less than $10 \%$.

The regional tides are semi-diurnal and range between 1.5 and $3.5 \mathrm{~m}$ during the neap and spring tide periods, respectively. No assessment of the tidal behavior along the estuary is available. However, a personal communication and visual inspection indicate that the tides reach the estuarine head (a small waterfall) at approximately $25 \mathrm{~km}$ upstream from the mouth of the
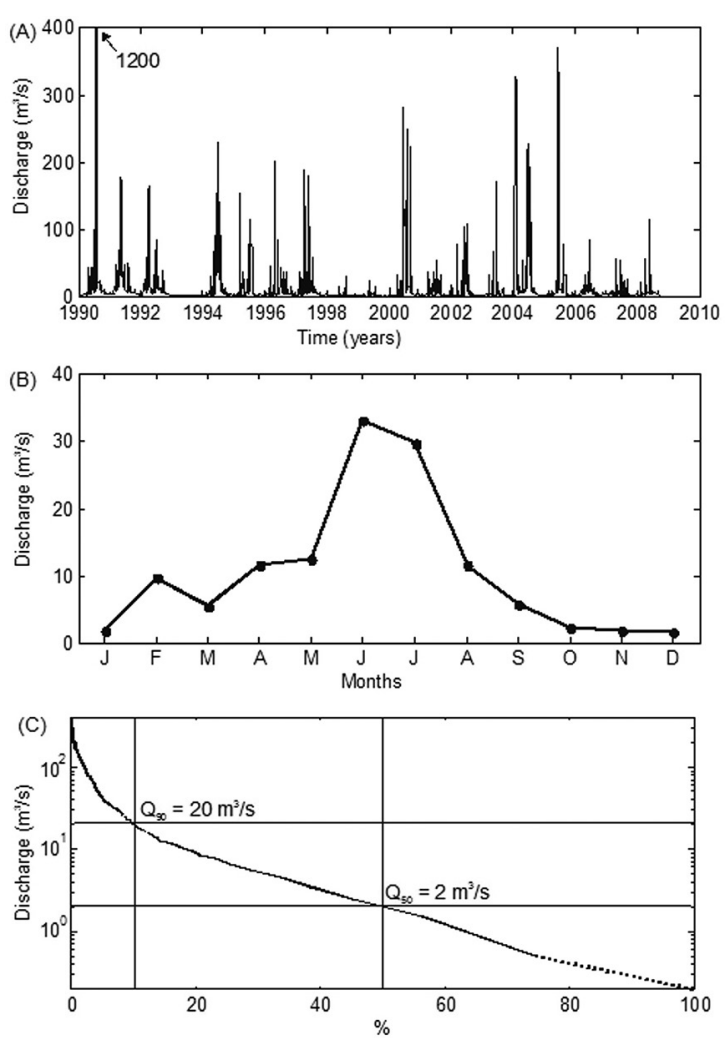

Figure 3. (A) Daily river discharge of the Capibaribe River at the São Lourenço da Mata gauge station. (B) Monthly average river discharge. (C) Flow duration curve indicating the $\mathrm{Q}_{50}$ and $\mathrm{Q}_{90}$ values.

estuary. No salt intrusion assessment was conducted, however, previous studies have reported that marine waters dominate the harbor area and the Pina Sound (STRETTA, 1959; KOENING et al., 1995; TRAVASSOS et al., 1993, FEITOSA et al., 1999).

The Capibaribe River Estuary receives high nutrient loads, which mainly result from anthropogenic sources. The levels of environmental deterioration have increased during recent decades in response to population growth and local industrial development (PARANAGUÁ et al., 2005), which have compromised the water quality in the estuary. OTTMANN and OTTMANN (1959) presented the very first assessment of the water quality in the estuary, followed many years later by KOENING et al. (1995) and, more recently, ANJOS et al. (2012) and NORIEGA et al. (2013). These authors noted the occurrence, in recent years, of a eutrophic state with high phytoplankton biomass, low transparency and low oxygen concentrations. In addition to eutrophication, industrial contamination also appears to have played an important role since metal contamination was reported by BRAYNER et al. $(2001 ; 2003)$ and MACEDO et al. (2007). 


\section{MATERIAL AND METHODS}

An oceanographic campaign was conducted to collect information regarding water level, current velocity and direction, salinity, temperature and SPM during a complete tidal cycle (e.g. KJERFVE, 1990). The campaign was undertaken on September 18th, 2012, corresponding to a spring tide, during the dry season, Data collection began at 6:00 and continued to 19:00 (i.e., covering a period of 13 hours). The sampling site was located nearly $3 \mathrm{~km}$ upstream from the estuarine mouth (Longitude 34.8736 West and Latitude 8.0701 South, Figure 1), where the estuarine channel is approximately $280 \mathrm{~m}$ wide, $8 \mathrm{~m}$ deep in the thalweg, with no intertidal areas.

Water level and current velocity were recorded with an acoustic Doppler current profiler (ADCP) (by Nortek A/S model Aquadopp Profiler of 1,000 kHz). The instrument was moored at the channel thalweg at a depth of $9 \mathrm{~m}$. The ADCP was programed to record 2-min averages (burst length) at $2 \mathrm{~Hz}$ pings with a vertical resolution of $0.35 \mathrm{~m}$. Bursts were recorded every 10 minutes during the sampling period. Vertical profiles of salinity and temperature were recorded with a YSI Castaway CTD next to the ADCP mooring site at half-hourly intervals. Salinity was reported as absolute salinity $(\mathrm{g} / \mathrm{kg})$ in accordance with the Thermodynamic Seawater Equation - TEOS-10 (http://www.teos-10.org/).

Values of SPM were obtained from the ADCP records by using acoustic backscatter (ABS) (ZALESKI; SCHETTINI, 2006; SCHETTINI et al., 2010b). The commercially available ADCP records echo intensity (counts units), which provides signal quality control. The signal is linearly converted into acoustic power (in decibels, $\mathrm{dB}$ ) and is corrected for the instrument's basal noise and the two-way travel by using the sonar equation, which corrects for beam aperture and water absorption (e.g., DEINES, 1999).

The ABS is an indirect measurement of water turbidity, which can be correlated with the SPM, a calibration curve being required to convert $\mathrm{ABS}$ into SPM. The calibration curve of SCHETTINI et al. (2013) was used in this case. That curve was obtained by the same instrument but in the Caravelas Estuary, Bahia. Both estuaries drain the same geological formation, the Tertiary deposits of the Barreiras Group (e.g. BIGARELLA, 1975), and the equation provides a reasonable proxy for the SPM concentration in the Capibaribe River Estuary. This is weak reasoning considering the very different settings of the two systems, although the values surely fit into the expected spectrum of SPM values, ranging from tens to hundreds of $\mathrm{mg} / \mathrm{l}$.

Current velocity data were decomposed into longitudinal and transversal components with respect to the channel orientation. The seaward longitudinal component was considered positive. The CTD data were synchronized with the current velocity data. All of the data were reduced to non-dimensional sigma coordinates and were resampled to provide an equal number of vertical samples for all of the temporal vertical profiles.

The mechanisms of advective transport of salt and SPM were calculated in order to identify the dominant processes. We adopted the reasoning of MIRANDA et al. (2002), which in its turn had been based on the earlier studies of BOWDEN (1963), FISHER (1976), HUNKINS (1981), DYER (1974) and KJERFVE (1986). The calculation is based on the hypothesis of a laterally homogeneous cross-section, which is - in the present case - a reasonable hypothesis. Lateral effects can be important in the salt and other properties balance (e.g. LERCZAK et al., 2006), and we can expect lateral variability to be even higher in shallow estuaries (e.g., LI; O'DONNELL, 1997). Therefore, despite the limitations of the results they highlight the dominant processes clearly.

The longitudinal velocity component $u$, the salinity or any other scalar property $s$ and the depth $h$ can be decomposed as

$$
\begin{aligned}
& u(x, z, t)=u_{a}(x)+u_{t}(x, t)+u_{s}(x, z)+u^{\prime}(x, z, t) \\
& s(x, z, t)=s_{a}(x)+s_{t}(x, t)+s_{s}(x, z)+s^{\prime}(x, z, t) \\
& h(x, t)=h_{a}(x)+h_{t}(x, t)
\end{aligned}
$$

where the subscript denotes the time and depthaveraged (for $u$ and $s$ ) value; the subscript denotes the instantaneous depth-averaged value; the subscript $\mathrm{S}$ denotes the time-averaged value at each level; the prime symbol denotes the residuals. The total transport of salt for one or more tidal cycles, $T_{S}$, is given by

$$
T_{S}=\frac{1}{T} \int_{0}^{T} \int_{0}^{h} u s d z d t
$$

where $T$ is the semi-diurnal tidal cycle period of 12.41 hours. The substitution of Eq. 1 in Eq. 2 produces 32 terms, of which only 7 have physical significance and/or are non-zero. Thus, the salt transport, or that of any scalar, can be written as

$$
\begin{aligned}
& T_{S}=u_{a} h_{a} S_{a}+<h_{t} u_{t}>s_{a}+h_{a}<u_{t} s_{t}>+ \\
& h_{a}<\overline{u^{\prime} s^{\prime}}>+<u_{t} s_{t} h_{t}>+h_{a} \overline{u_{s} s_{s}}+u_{a}<s_{t} h_{t}>
\end{aligned}
$$


The brackets $<>$ and the overbar denote time and depth-averaging operations, respectively. MIRANDA et al. (2002) attributed the physical meaning of the terms to (i) fluvial discharge, (ii) Stokes drifts, (iii) tidal correlation, (iv) tidal pumping, (v) tidal shear, (vi) gravitational circulation and (vii) wind fluctuations (MIRANDA et al., 2002).

\section{RESULTS}

Table 1 includes a summary of the results, including the mean, minimum and maximum current velocity, salinity, temperature and SPM. The peak ebb and flood currents were nearly symmetrical, with the ebb currents (positive) being slightly stronger than the flood currents. The depthaveraged residual velocity was $0.02 \mathrm{~m} / \mathrm{s}$ landward. The mean salinity was $34 \mathrm{~g} / \mathrm{kg}$, and varied between 25 and 37 $\mathrm{g} / \mathrm{kg}$, this latter being the salinity value of shelf waters. The temperature varied by $1.5^{\circ} \mathrm{C}$, with a mean of $27^{\circ} \mathrm{C}$. The mean SPM was approximately $100 \mathrm{mg} / \mathrm{l}$, and varied between 10 and $600 \mathrm{mg} / \mathrm{l}$.

Table 1. Summary of current velocity, salinity, temperature and suspended sediment concentration (SSC) values in the Capibaribe Estuary. Positive current values indicate seaward flows.

\begin{tabular}{lccc}
\hline & Mean & Minimum & Maximum \\
\hline Velocity $(\mathrm{m} / \mathrm{s})$ & -0.02 & -0.58 & 0.63 \\
Salinity $(\mathrm{g} / \mathrm{kg})$ & 34.1 & 25.6 & 36.7 \\
Temperature $\left({ }^{\circ} \mathrm{C}\right)$ & 26.7 & 26.3 & 27.8 \\
SPM $(\mathrm{mg} / \mathrm{l})$ & 108 & 8 & 630 \\
\hline
\end{tabular}

The tidal height was $2.44 \mathrm{~m}$, with the low water (LW) and high water (HW) occurring at 11.15 and 17.30, respectively, with a lapse of 6:15. The almost symmetrical ebb and flood ebb currents and the respective symmetrical tidal phases indicate a clearly pure tidal signal, or, by exclusion, tidal asymmetries (e.g. Friedrichs \& Aubrey, 1988) are not a concern in the lower Capibaribe estuary. The LW and HW slack waters were both delayed by approximately 30 minutes (Figure 4A). The relationship between tidal phase and current velocity is shown in the current velocity stage diagram (Figure 4B) that indicated a nearly $90^{\circ}$ phase lag between the tides' extreme levels and current peaks. This is an expected result for short estuaries whose length is much shorter than that of the tidal wave (FRIEDRICHS, 2010). The good fit between the beginning and end of the campaign is also noteworthy. This indicates the very slight effects of semi-diurnal tidal inequalities, making the residuals' values straightforward. Thirteen-hour tidal experiments usually fail to achieve this closure, introducing a bias in the residuals since after the end of the tidal cycle the volume in the tidal basin will be different.

The temporal and vertical field distributions of current velocity, salinity, temperature and SPM are presented in Figure 5. The results are also presented in Figure 6 as temporal variations of depth-averaged values and for each level (left panels) as vertical variations of time averaged and instantaneous values. Because temperature has little influence on the estuarine dynamics, it is not shown in Figure 6, although it was considered for density calculations.

The current velocity displayed a unidirectional and sheared profile most of the time, except at the end of the ebb and the beginning of the flood (around LW), when isolines were slightly tilted toward ebb. This indicated bidirectional flow, with inflow near the bottom and outflow near the surface, consistent with gravitational circulation. The highest stratification developed around this slack period, caused by a tidal intrusion front. In addition, the water column was nearly vertically homogenous during the remaining periods. The minimum salinity values occurred at the surface and during LW (reaching $26 \mathrm{~g} /$ $\mathrm{kg}$ ) when the highest temperature $\left(27.5^{\circ} \mathrm{C}\right)$ was recorded. The maximum vertical salinity and temperature surface to bottom differences were $10 \mathrm{~g} / \mathrm{kg}$ and $0.8^{\circ} \mathrm{C}$, respectively. The SPM presented higher values near the bed and was correlated with the maximum ebb and flood currents, although the concentration during the ebb was about $4 \mathrm{x}$ higher than the values recorded during the flood.

The estuarine vertical structure can be summarized as a continuous competition between the fresh water inflow providing buoyancy flux and tidal energy dissipation producing mixing. The gradient Richardson number represents this by weighting the buoyancy and shear production. The buoyancy is scaled in terms of vertical stratification by the Brunt-Vaisala frequency $N^{2}=g / \rho \partial \rho / \partial z$, and the shear production is scaled in terms of squared vertical shear $S^{2}=(\partial u / \partial z)^{2}$, by

$$
R i=\frac{N^{2}}{S^{2}}
$$

where $\mathrm{g}$ is the gravity; $\rho$ the density; $\mathrm{z}$ the vertical coordinate and $\mathrm{u}$ the current velocity. When $\mathrm{Ri}$ is $>0.25$, the stratification is stable, whereas when $\mathrm{Ri}<0.25$ the vertical shear will overcome the stratification and produce 

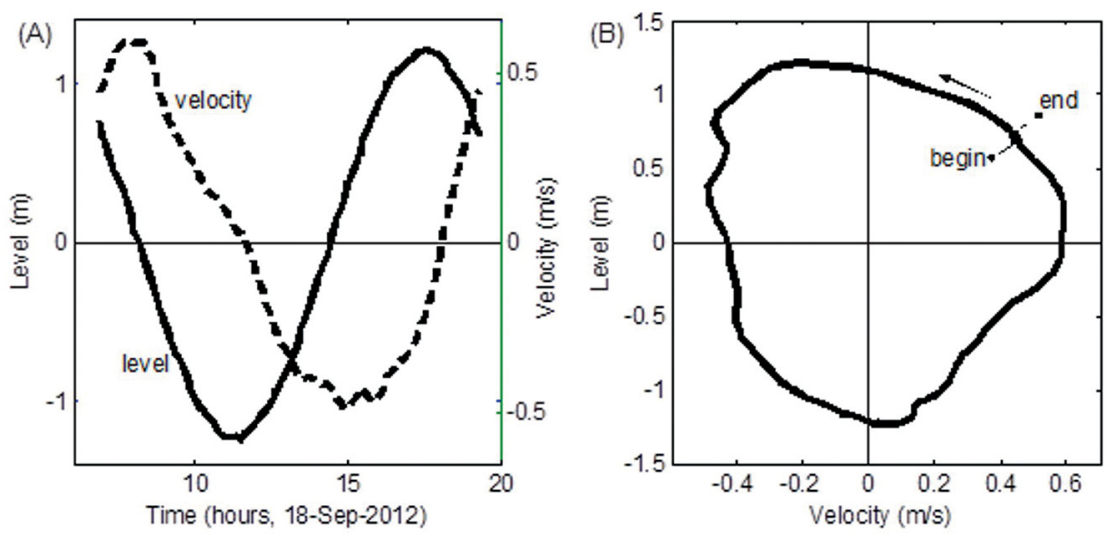

Figure 4. The time series of water level $(\mathrm{m})$ and depth-averaged current velocity $(\mathrm{m} / \mathrm{s})$ and the tidal-stage/current velocity diagram (evolves counterclockwise).

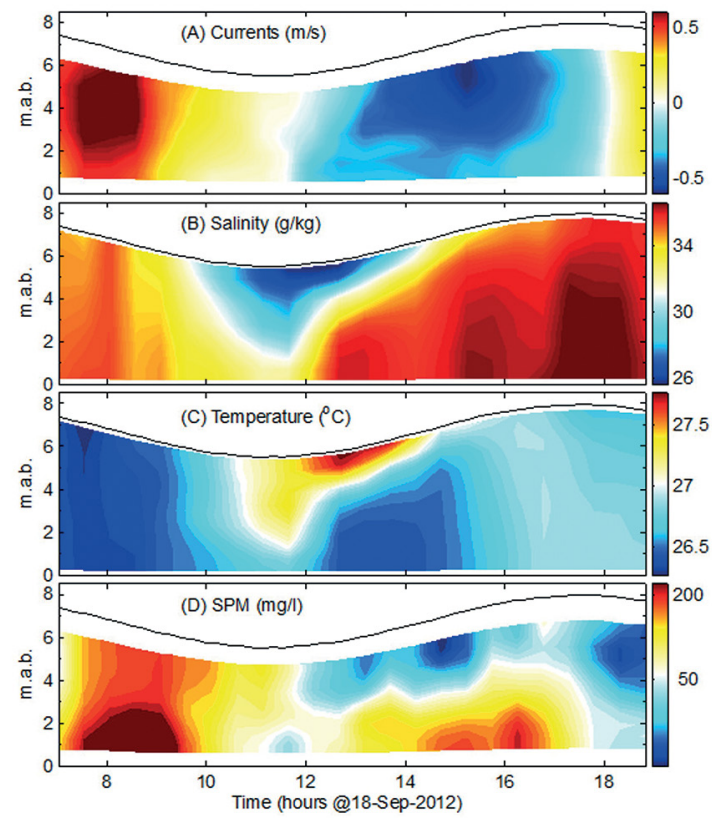

Figure 5. Vertical and temporal field distributions of (A) current velocity $(\mathrm{m} / \mathrm{s})$, (B) salinity $(\mathrm{g} / \mathrm{kg}),(\mathrm{C})$ temperature (oC) and (D) suspended particulate matter (SPM, mg/l) in the Capibaribe Estuary on 18 Sept. 2012. Positive current velocities indicate seaward flow.

mixing. Figure 7 presents the field distribution of Ri and the contribution of $\mathrm{N}^{2}$ and $\mathrm{S}^{2}$. Stability prevails in the water column during most of the period at the upper layer, and throughout the water column during low water. Unstable conditions were recorded in the lower layer during both ebb and flood. The distribution of $\mathrm{N}^{2}$ follows that of salinity, being higher just after the low water and in the upper layer. Higher shear was recorded in the lower layer, mainly during the flood phase.

The instantaneous salt and SPM transport, given by the product of depth averaged values and velocity, are shown in Figure 8. Salt transport was nearly symmetrical between the flood and ebb phases, with maximum values of -17.4 and $21.2 \mathrm{~kg} / \mathrm{m}^{2} \mathrm{~s}$, respectively. The mean residual salt transport was landward at $-0.64 \mathrm{~kg} / \mathrm{m}^{2} \mathrm{~s}$. The SPM transport was remarkably asymmetrical, with maximum ebb and flood transport values of 0.16 and $-0.05 \mathrm{~kg} / \mathrm{m}^{2} \mathrm{~s}$, respectively. The residual transport was seaward at 0.01 $\mathrm{kg} / \mathrm{m}^{2} \mathrm{~s}$.

The decomposition of the advective transport of salt and SPM are presented in Table 2. The higher term for the salt transport was the Stokes Drift, being one order of magnitude greater than the other non-zero terms, the tidal correlation and fluvial advection, all landwards. The 

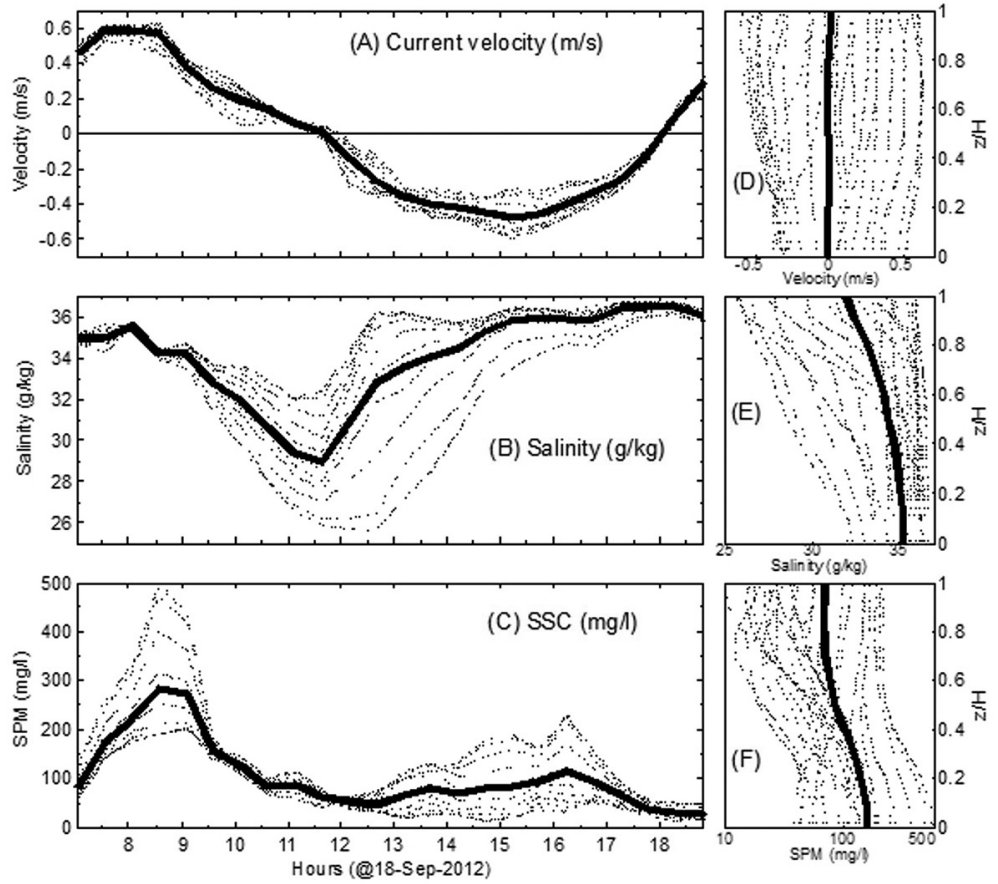

Figure 6. Left panels: time series of the depth averaged (bold line) and of each level (dashed lines) for (A) current velocity, (B) salinity and (C) suspended particulate matter (SPM). Right panels: vertical profiles of time averaged (bold line) and instantaneous profiles for (D) current velocity $(\mathrm{m} / \mathrm{s})$, (E) salinity $(\mathrm{g} / \mathrm{kg})$ and $(\mathrm{F}) \mathrm{SPM}(\mathrm{mg} / \mathrm{l})$. Positive current velocities indicate seaward flow.
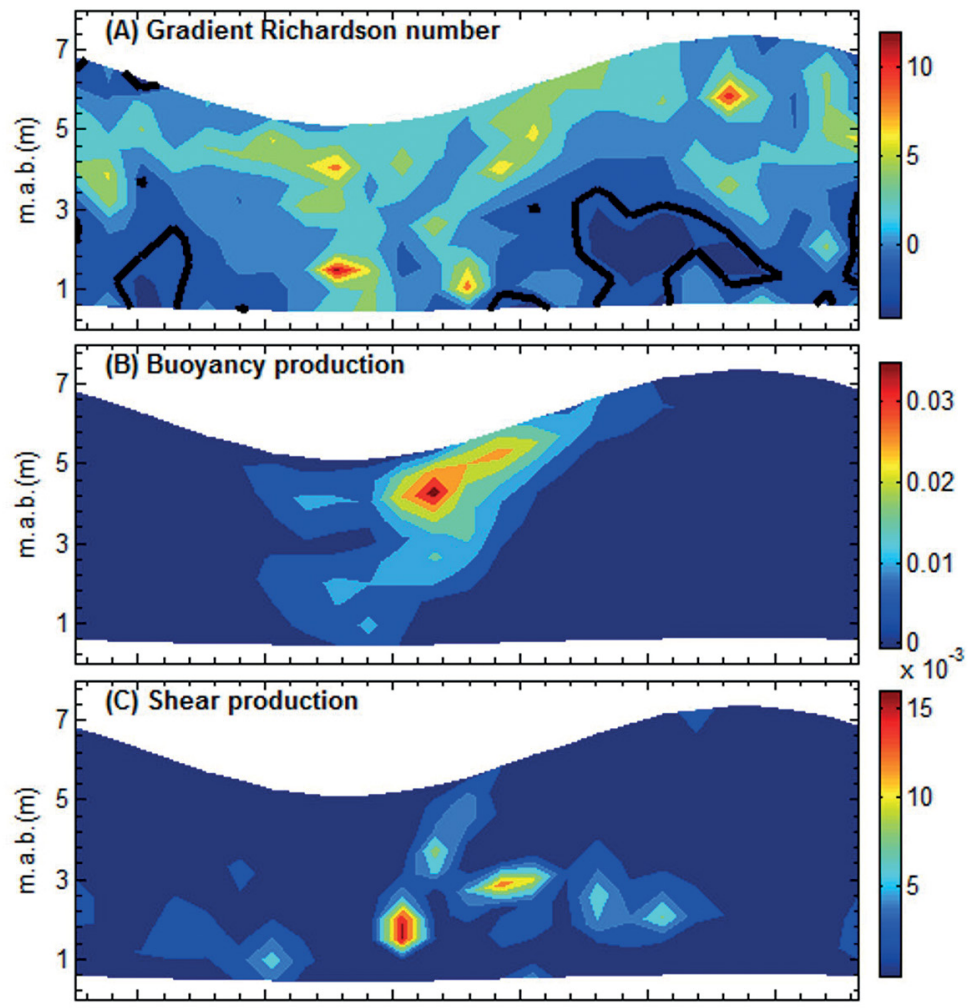

Time (hours @18-Sep-2012)

Figure 7. (A) Vertical and temporal field of gradient Richardson number, with the respective contributions of the buoyancy (B) and shear (C) production. The black line represents the threshold value of 0.25 . 


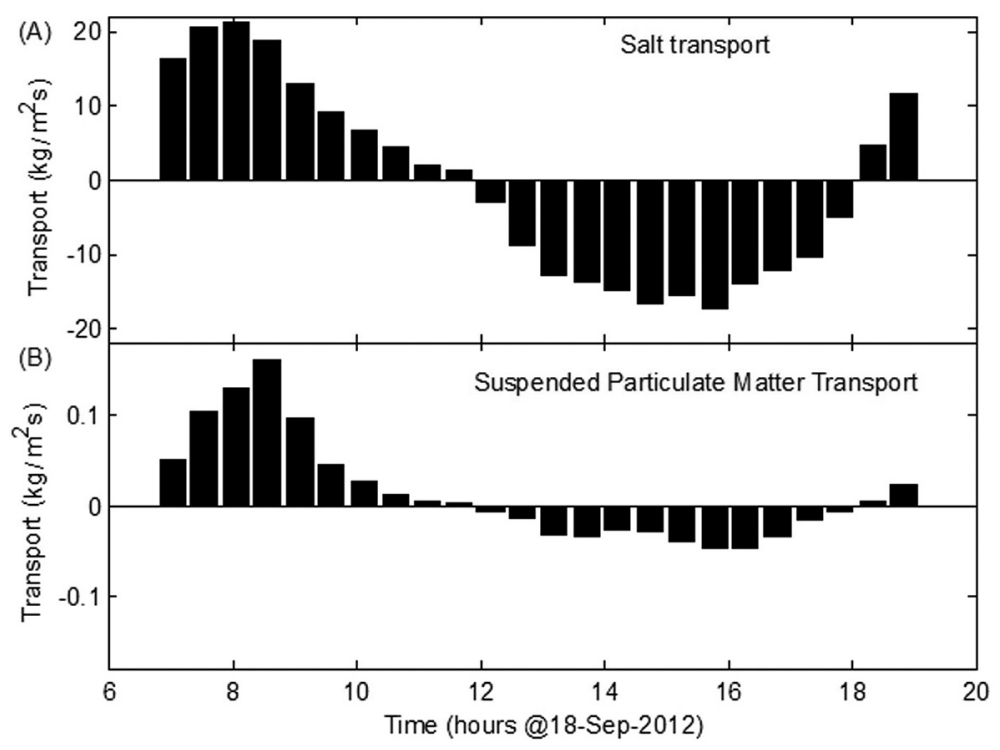

Figure 8. Instantaneous salt (A) and suspended particulate matter (B) transport during the experiment.

Table 2. Results of the decomposition of the advective transport of salt and SPM.

\begin{tabular}{lll}
\hline Term & Salt $(\mathrm{kg} / \mathrm{m} \mathrm{s})$ & $\mathrm{SPM}(\mathrm{kg} / \mathrm{m} \mathrm{s})$ \\
\hline Fluvial advection & -0.2 & -0.6 \\
Stokes drift & -1.1 & -3.1 \\
Tidal correlation & -0.4 & 90.7 \\
Gravitational circulation & 0.0 & -0.8 \\
Tidal pumping & -0.1 & 3.2 \\
Tidal shear & 0.0 & -4.7 \\
Non-stationary & 0.0 & 0.0 \\
\hline
\end{tabular}

highest term for the SPM transport was the tidal correlation (seawards), two orders of magnitude greater than the tidal pumping (seawards), Stokes drift and tidal shear (both landwards).

\section{DISCUSSION}

The discharge of the Capibaribe River is driven by the regional semi-arid climate and is affected by large scale phenomena, such as El Niño (SILVA et al., 2010). Negative anomalies in precipitation are related to positive El Niño years (GLANDZ, 2001; BERLATO; FONTANA, 2003). However, this relationship is not unequivocal (KANE; TRIVEDI, 1988; KANE, 1992; 1997) because the regional precipitation is also affected by anomalies in the Tropical Atlantic Ocean (MOURA; SHUKLA, 1981; SILVA et al., 2010). This picture highlights the highly random nature of rainfall events, which in climatological terms are concentrated in June and July. River discharge events exceeding the mean value are expected to occur in less than $10 \%$ of the time (i.e. 35 days per year). Thus, tide dominant conditions will prevail most of the time in the estuarine hydrodynamics.

Fresh water inflow of RMR into the estuary is not negligible. A conservative gross estimate of human water use in Brazil is of $0.2 \mathrm{~m}^{3} /$ day (BARRETO, 2008), which, weighted by RMR population, represents a freshwater inflow of $\sim 8.5 \mathrm{~m}^{3} / \mathrm{s}$, which is more than three times the Capibaribe River's $\mathrm{Q}_{50}$. Contrary to the river discharge driven by random meteorological events, this fresh water inflow is deterministic and steady. It is likely that the Capibaribe estuary could formerly have been subject to a low inflow of freshwater which might even have led to a hypersaline regime (e.g. LARGIER, 2010), as still happens in other estuaries in the Northeast of Brazil (Mossoró estuary, VALLE-LEVINSON \& SCHETTINI, 2016). However, the city's water demand keeps the fresh water inflow baseline at higher levels even during the dry period. This water budget alteration has also been reported for the Jaguaribe estuary, also in the Northeast of Brazil (FROTA et al., 2013).

The salinity variation over the period of the experiment of $10 \mathrm{~g} / \mathrm{kg}$ reflects the dilution of marine water with freshwater. The observed salinity variations during the experiment indicated that the salinity varied in phase with the height of the tide, with minimum values around $\mathrm{LW}$, when the higher stratification of nearly $1 \mathrm{~g} / \mathrm{kg}$ per $\mathrm{m}$ of water column occurred. The decrease in the salinity accompanying the fall in the water level is a direct 
indication of the marine water dilution up estuary, and the advection of this water mass according to the tides. The higher stratification at LW can be explained in terms of 1) buoyancy flux, as the brackish lighter waters will flow over denser marine waters, 2) tidal straining caused by vertical shear of the flow which will lead to increased stratification during the ebb, and 3) morphological effects, seeing that the upstream stretch from the sampling site rapidly shallows to $<3 \mathrm{~m}$.

The competition between tidal mixing and stratification can be weighted using the circulation-stratification classification of HANSEN and RATTRAY (1966). When considering the time-averaged results over a tidal cycle, the stratification is scaled as the ratio of the difference between the bottom to surface salinity and the depthaveraged salinity: $\left(S_{B}-S_{S}\right) / \bar{S}=0.097$. The circulation parameter can be scaled by the ratio of the surface velocity to the depth-averaged velocity: $u_{s} / \bar{u}=1.32$. These values, in HANSEN and RATTRAY's diagram, classify the estuary as type $2 \mathrm{a}$, or as a partially mixed estuary with low stratification under the conditions sampled. By using the circulation/stratification scheme it is possible to obtain a parametric value $v$, which represents the advection to diffusion ratio of salt transport (MIRANDA et al., 2002). The present value of $v=0.95$ indicates that $95 \%$ of the salt (and as a proxy for other dissolved scalars) is transported by diffusion, while $5 \%$ is transported by advection. As a rule of thumb, diffusion in estuaries is the role of the tides, which cause mixing, while residual advection is the role of river discharge. This results in the dominance of the tide over the circulation processes already commented on. Furthermore, considering that the fresh water inflow is mostly due to the wastewaters, we may hypothesize that the estuary may formerly have presented well mixed conditions.

GEYER and MACCREADY (2014) have proposed a new way to weight the relative roles of fresh water inflow (stratification) and tides (circulation and mixing). The estuary condition can be summarized by weighting the buoyancy production induced by river discharge scaled by a fresh water Froude number $F_{r f}$, in relation to a mixing parameter $M$ which accounts for the tidal mixing effects. The freshwater Froude number is $F_{r f}=U_{R} /\left(\beta g S_{0} H\right)^{1 / 2}$, where $\mathrm{U}_{R}$ is the net velocity due to river inflow, $\beta$ is the saline contraction coefficient $\left(\approx 7.7 \times 10^{-4}\right), g$ is the gravity acceleration, $S_{0}$ is the coastal water salinity and $H$ the depth. The mixing parameter is $M=\left(C_{D} U_{t}^{2} / \omega N_{0} H^{2}\right)^{1 / 2}$, where $C_{\mathrm{D}}$ is the bottom drag coefficient $\left(\approx 2 \times 10^{-3}\right), U_{\mathrm{t}}$ is the amplitude of tidal currents, $\omega$ is the tidal frequency $\left(2.24 \times 10^{-5} \mathrm{~s}^{-1}\right)$, and $N_{0}$ is the buoyancy frequency given by $N_{0}=\left(\beta g S_{0} / H\right)^{1 / 2} . U_{R}$ is obtained by dividing the river discharge by the cross sectional area. Assuming that in the dry season the river discharge is of the order of 10 $\mathrm{m}^{3} \mathrm{~s}^{-1}$, the cross-sectional area is of about $1,500 \mathrm{~m}^{2}$, so $U_{R}$ $\approx 7 \times 10^{-3}, S_{0}$ and $H$ are $37 \mathrm{~g} \cdot \mathrm{kg}^{-1}$ and $7 \mathrm{~m}$, respectively, and $F_{r f} \approx 5 \times 10^{-3}$. From observations $U_{T}$ is $0.5 \mathrm{~m} . \mathrm{s}^{-1}$, which yields $\mathrm{M} \approx 0.7$. These coordinates in GEYER and MACCREADY's diagram classify the Capibaribe estuary as a partially mixed estuary, agreeing with the HANSEN and RATTRAY's approach.

The predominant type of circulation in a given estuary is a proxy for sediment transport and trapping efficiency (DYER, 1995). Estuaries are filters for land-borne materials at the continent-ocean interface (SCHUBEL; CARTER, 1984), and the trapping efficiency depends in large part on the predominant estuarine circulation. Riverdominated systems usually produce highly stratified conditions and have low trapping efficiency. However, partially mixed estuaries are efficient filters and can even import sediments from the inner shelf as well (SCHETTINI et al., 2006; 2013). The present experiment allowed us to investigate the most energetic tidal current conditions at spring tide and the resulting transport due to water-bed sediment exchanges. Results from another tide-dominated tropical estuary, the Caravelas Estuary in Brazil, showed a difference of one order of magnitude in the SPM concentration between the spring and neap tide conditions, from 100 to $15 \mathrm{mg} / \mathrm{l}$, respectively. This difference also accounted for considerable transport during spring tides, and nearly nil transport during neap tides (PEREIRA et al., 2010; SCHETTINI; MIRANDA, 2010a). We may expect a similar pattern for the Capibaribe estuary in terms of SPM behavior.

Time and depth-averaged transport values showed residual landward water and salt transport, and seaward transport for SPM. This result is robust even arising as it does from a single tidal cycle survey. The water level at the end of the campaign was nearly the same as that at the beginning of the campaign (Figure 4), which is only rarely achieved in 13-hour surveys. This means that the estuarine volume was the same at the beginning and end of the campaign. Small water level inequalities, and so volume differences, can introduce a bias in the calculation of residuals (e.g., SCHETTINI; MIRANDA, 2010a). The causes of the residuals could be explained by lateral variability of the flow (e.g., DYER et al., 1992; CHANT; 
WILSON, 1997), although the relative narrowness of the system suggests lateral homogeneity. On the other hand, the estuary has a complex network of channels and islands which could favor residual water transport as a function of tidal behavior progression (e.g., GUYONDET; KOUTITONSKY, 2008; SCHETTINI et al., 2013). Therefore, seaward residual transport of SPM is not tied to the water and salt transport.

SPM is a highly non-conservative water property, as it can be advected from somewhere else or exchanged between water column and bed during a tidal cycle (e.g. SIEGLE et al., 2009). The water-bed exchange processes are a function of the yield shear stress by currents and bed properties (WINTERWERP; VAN KESTEREN, 2004). The timeaveraged vertical profile of the SPM showed an increased concentration near the bed, which indicates that the bed is the main source. Further, the SPM distribution agrees nicely with the gradient Richardson number distribution, with higher values of SPM related to $\mathrm{Ri}<0.25$, near the bed. Therefore, the tidal variability of SPM concentrations was asymmetrical, with much higher values during the ebb than the flood, even with ebb and flood current peaks being nearly symmetrical. This can be interpreted as a morphological control causing SPM advection from the upper stretch of the estuary. The study site was dredged to its present depth during the last century, and the limit of the dredged area is hundreds of meters up estuary, where the depth is reduced to $2-3 \mathrm{~m}$ in the area called Pina Sound. The shallowness would allow for higher resuspension rates due to wave action and higher current speeds.

It is expected to find landward residual SPM transport in partially mixed estuaries (SCHUBEL; CARTER, 1984; DYER, 1995), but we recorded inverse behavior. It is likely that there is a morphological control in the SPM concentration asymmetries, with residual transport seawards. Could this material reach the estuary mouth and be exported to the inner shelf? The exportation of SPM is certainly to be expected as a result of events of considerable river discharge (e.g. SCHETTINI, 2002b), but could it not occur under low river discharge and tide dominated conditions? A recent study of organic pollutants along the shelf-estuarine environment (MACIEL et al., in press) has indicated that there is a strong negative gradient seawards, suggesting a high retention rate, but also that there are estuarine borne pollutants reaching the adjacent shelf. Figure 9 shows the cumulative displacement calculated as the sum of the instantaneous depth-averaged velocities integrated over the sampling interval. The

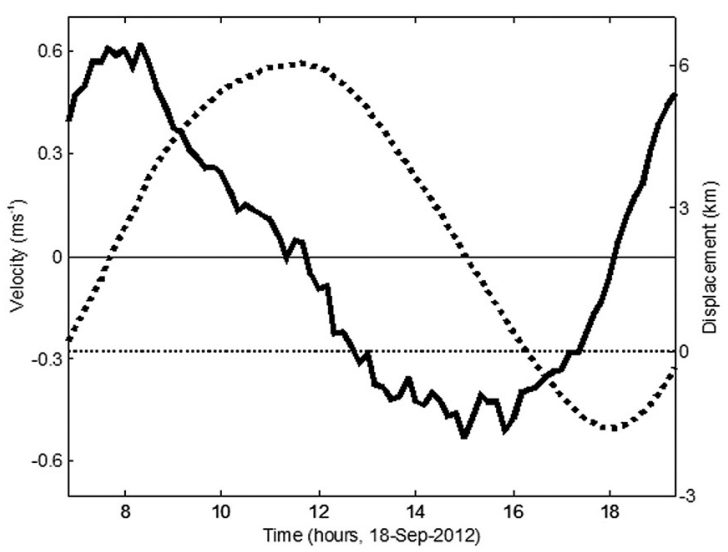

Figure 9. Time series of the depth-averaged current velocity $(\mathrm{m} / \mathrm{s}$, solid line) and the cumulative displacement (km, dashed line).

vertical distance between the inflection points provides an estimate of the tidal excursion, which is the potential displacement of a water parcel during a tidal cycle. The tidal excursion was approximately $7 \mathrm{~km}$, which is more than twice the distance between the sampling site and the estuarine mouth. Since the estuary's cross section does not vary very much before reaching the mouth, and thus the hydraulic regime would be nearly the same, it is to be expected that some SPM can reach the adjacent shelf, even under tide dominated conditions.

\section{CONCLUSIONS}

This study presents the first assessment of hydrographic and hydrodynamic aspects of the Capibaribe Estuary in tropical semi-arid Brazil. It has also described the potential effects of those physical aspects on the transport of scalars during spring tides with low river discharge. The main conclusions are:

1. Freshwater inflow to the estuary is affected by urban wastewater discharge, which can attain as much as three times the river inflow during the dry season;

2. The lower estuary displays a partially mixed vertical structure;

3. The residual water and salt transport is into the estuary. This suggests a complex circulation because of the presence of islands and which must be investigated further;

4. The residual transport of SPM is seaward, decoupled from the salt and water transport, which was interpreted as morphological control;

5. It is likely that the lower estuary is a source of SPM to the adjacent shelf. 


\section{ACKNOWLEDGEMENTS}

This study was partially funded by the Science Foundation of Pernambuco (Fundação de Amparo à Ciência e Tecnologia do Estado de Pernambuco) FACEPE grant APQ-0079-1.08/11, project MuGloEst (Global Changes in Estuaries). CAFS is grateful for the support of CNPq No 308665/2013-9. AVL expresses his thanks for the visiting Professor Scholarship and ECT thanks FACEPE and CNPq for their financial support.

\section{REFERENCES}

ANDREOLI, R. V.; KAYANO, M. T. A importância relativa do atlântico tropical sul e pacífico leste na variabilidade de precipitação do Nordeste do Brasil. Rev. Bras. Meteorol., v. 22, n. 1, p. 63-74, 2007.

ANJOS, D. L.; PASSAVANTE, J. K. O.; SILVA-CUNHA, M. G. G.; HONORATO DA SILVA, M. Biomassa fitoplanctônica correlacionada aos fatores hidrológicos no estuário do rio Capibaribe (Recife, Pernambuco, Brasil). Trop. Oceanogr., v. 40, n. 1, p. 167-184, 2012.

BARRETO, D. Perfil do consumo residencial e usos finais da água. Ambient. Constr., v. 8, n. 2, p. 23-40, 2008

BERLATO M. A.; FONTANA, D. C. El Niño e La Niña: impactos no clima, na vegetação e na agricultura do Rio Grande do Sul; aplicações de previsões climáticas na agricultura. Porto Alegre: UFRGS, 2003. 110 p.

BIGARELLA, J. J. The Barreiras Group in Northeastern Brazil. An. Acad. Bras. Ciênc., v. 47, p. 365-393, 1975.

BOWDEN, K. F. The mixing processes in a tidal estuary. J. Air Wat. Pollut., v. 7, p. 343-356, 1963.

BRAYNER, F. M. M.; SILVA, H. K. P.; BARBOSA, A. M. F. Speciation of heavy metals in estuarine sediments in the Northeast of Brazil. Environ. Sci. Pollut. Res. Int., v. 8, n. 4, p. $269-274,2001$

BRAYNER, F. M. M.; BARBOSA, A. M. F.; SILVA, H. K. P.; MELO, L. V. Behaviour of heavy metals in the estuarine area of the Capibaribe River in the Northeast of Brazil. J. Phys. IV JP, v. 107, n. 1, p. 221-225, 2003.

CASTRO, I. B.; ALVES DE LIMA, A. F.; BRAGA, A. R. C.; ROCHA-BARREIRA, C. A. Imposex in two muricid species (Mollusca: Gastropoda) from the northeastern Brazilian coast. J. Braz. Soc. Ecotoxicol., v. 2, n. 1, p. 81-91, 2007.

CHACON, V. O Capibaribe e o Recife: história social e sentimental de um rio. Recife: Secretaria de Educação e Cultura de Pernambuco, 1959. 62 p.

CHANT. R. J.; WILSON, R. E. Secondary circulation in a highly stratified estuary. J. Geophys. Res., v. 102, n. C10, p. $23207-$ $23215,1997$.

DEINES, K. L. Backscatter estimation using broadband acoustic Doppler current profilers. San Diego: Proceedings IEEE 6th Working Conference on Current Measurements, 1999. p. 249-253.

DYER, K. R. The salt balance in stratified estuaries. Estuar. Coast. Mar. Sci., v. 2, p. 273-281, 1974.

DYER, K. R. Sediment transport processes in estuaries. In: PERILLO, G. M. E. (Ed.). Geomorphology and sedimentology of estuaries. New York: Elsevier, 1995. p. 423-449.
DYER, K. R. Estuaries: a physical introduction. 2nd ed. New York: John Wiley \& Sons, 1997. $195 \mathrm{p}$.

DYER, K. R.; GONG, W. K.; ONG, J. E. The cross sectional salt balance in a tropical estuary during a lunar tide and a discharge event. Estuar. Coast. Shelf Sci., v. 34, p. 579- 591, 1992

FEITOSA, F. A. N.; NASCIMENTO, F. C. R.; COSTA, K. M. P. Distribuição espacial e temporal da biomassa fitoplanctônica relacionada com parâmetros hidrológicos na Bacia do Pina, Recife-PE. Trab. Oceanog. Univ. Fed. Pernamb., v. 27, n. 2, p. 1-13, 1999.

FISHER, H. B. Mixing and dispersion in estuaries. Ann. Rev. Fluid Mech., v. 8, p. 107-133, 1976.

FOFONOFF, N. P.; MILLARD JR, R. C. Algorithms for computation of fundamental properties of seawater. Paris: Uniesco Technical Papers in Marine Science, 1983.

FRIEDRICHS, C. T. Barotropic tides in channelized estuaries. In: VALLE-LEVINSON, A. (Ed.). Contemporary Issues in Estuarine Physics. Cambridge: Cambridge University Press, 2010. p. 27-61.

FRIEDRICHS, C. T.; AUBREY, D. G. Non-linear tidal distortion in shallow well-mixed estuaries: a synthesis. Estuar. Coast. Shelf Sci., v. 27, p. 521-545, 1988.

FROTA, F. F.; PAIVA, B. P.; SCHETTINI, C. A. F. Intra-tidal variation of stratification in a semi-arid estuary under the impact of flow regulation. Braz. J. Oceanogr., v. 61, n. 1, p. 23-33, 2013

GEYER, W. R.; MACCREADY, P. The estuarine circulation. Ann. Rev. Fluid Mech., v. 46, p. 175-197, 2014.

GLANDZ, M. H. Currents of change: impacts of El Niño and La Niña on climate and society. 2.ed. Cambridge: Cambridge University Press, 2001. 252 p.

GUYONDET, T.; KOUTITONSKY, V. G. Tidal and residual circulations in coupled restricted and leaky lagoons. Estuar. Coast. Shelf Sci., v. 77, n. 3, p. 396-408, 2008.

HANSEN, D. V.; RATTRAY, M. New dimensions on estuarine classification. Limnol. Oceanogr., v. 11, p. 319-326, 1966.

HUNKINS, K. Salt dispersion in the Hudson Estuary. J. Phys. Oceanogr., v. 11, p. 729-738, 1981.

IBGE - Instituto Brasileiro de Geografia e Estatística. Atlas Nacional do Brasil Milton Santos. Rio de Janeiro: IBGE, 2010. $307 \mathrm{p}$

KANE, R. P.; TRIVEDI, N. B. Spectral characteristics of the annual rainfall series for northeast Brazil, Clim. Chang., v. 13, p. 317-336, 1988

KANE, R. P. El Niño and La Niña events and rainfall in NE and South Brazil. Rev. Bras. Geofísica, v. 10, n. 2, p. 49-59, 1992.

KANE, R. P. Prediction of droughts in north-east Brazil: role of ENSO and use of periodicities. Int. J. Climatol., v. 17, p. 655$665,1997$.

KJERFVE, B. Circulations and salt flux in a well mixed estuary. In: VAN DE KREEK J. (Ed.). Physics of shallow estuaries and bays. Berlin: Springer-Verlag, 1986. p. 22-29.

KJERFVE, B. Manual for investigation of hydrological processes in mangrove ecosystems. Paris: UNESCO/UNDP, 1990. 79 p.

KOENING, M. L.; MACÊDO, S. J.; TRAVASSOS, P. E. P. F.; PASSAVANTE, J. Z. O. Biomassa fitoplanctônica no estuário do rio Capibaribe (Recife - Pernambuco - Brasil). Arq. Biol. Tecnol., v. 38, n. 4, p. 1071-1083, 1995. 
LARGIER, J. Low inflow estuaries: hypersaline, inverse, and thermal scenarios. In: VALLE-LEVINSON, A. (Ed.). Contemporary Issues in Estuarine Physics. Cambridge: Cambridge University Press, 2010. p. 247-272.

LERCZAK, J. A.; GEYER, W. R.; CHANT, R. J. Mechanisms driving the time-dependent salt flux in a partially stratified estuary. J. Phys. Oceanogr., v. 36, p. 2296-2311, 2006.

LI, C.; O'DONNELL, J. Tidally driven residual circulation in shallow estuaries with lateral depth variation. J. Geophys. Res., v. 102, n. C13, p. 27915-27929, 1997.

MACEDO, S. J.; PHILIPPINI DA SILVA, H. K.; BRAYNER, F. M. M.; DUARTE, M. M. M. B.; BARBOSA, A. M. F. Heavy metal concentrations in sediments of the Capibaribe river estuary in the Metropolitan Region of Recife, PernambucoBrazil. WIT Trans. Ecol. Environ., v. 102, p. 3-12, 2007.

MACIEL, D. C.; SOUZA, J. R. B.; TANIGUCHI, S.; BÍCEGO, M. C.; SCHETTINI, C. A. F.; ZANARDI-LAMARDO, E. The role of a tropical estuary faced to hydrocarbons contamination: sink or source to adjacent shelf? Sci. Total Environ., (In press).

MIRANDA, L. B.; CASTRO, B. M.; KJERFVE, B. Princípios de Oceanografia Física de estuários. São Paulo: Universidade de São Paulo, 2002. 424 p.

MOTTA SOBRINHO, M. A.; ANDRADE, A. C. O desafio da conservação de manguezais em áreas urbanas: identificação e análise de conflitos socioambientais no Manguezal do PinaRecife - PE - Brasil. Rev. Unim. Cient., v. 11, n. 1/2, p. 8-16, 2009.

MOURA, A. D.; SHUKLA, J. On the dynamics of droughts in northeast Brazil: observations, theory and numerical experiments with a general circulation model. J. Atmos. Sci., v. 38, p. 2653-2675, 1981.

NORIEGA, C. E.; SANTIAGO, M. F.; FAÇANHA, P.; SILVA, M. D. G. G.; SILVA, R. A.; MONTES, M. D. J. F.; ARAÚJO FILHO, M.; COSTA, A. M. P.; ESKINAZI LEÇA, E.; NEUMANN-LEITÃO, S. The instantaneous transport of inorganic and organic material in a highly polluted tropical estuary. Mar. Fresh. Res., v. 64, n. 6, p. 562-572, 2013.

OLIVEIRA, G. C. S.; SILVA JÚNIOR, J. P.; NÓBREGA, R. S.; GIRÃO, O. Uma abordagem da geografia do clima sobre eventos extremos de precipitação em Recife-PE. Rev. Bras. Geogr. Física, v. 2, p. 238-251, 2011.

OTTMANN, F.; OTTMANN, F. N. La maree de salinite dans le Capibaribe, Recife- Brasil. Trab. Instit. Biol. Mar. Oceanogr. Univ. Recife, v. 1, n. 1, p. 39-49, 1959.

PARANAGUÁ, M. N.; NEUMANN-LEITÃO, S.; NOGUEIRAPARANHOS, J. D.; SILVA, T. A.; MATSUMURA-TUNDISI, T. Cladocerans (Branchiopoda) of a tropical estuary in Brazil. Braz. J. Biol., v. 65, n. 1, p. 107-115, 2005.

PEREIRA, M. D.; SIEGLE, E.; MIRANDA, L. B.; SCHETTINI, C. A. F. Hidrodinâmica e transporte de material particulado em suspensão sazonal em um estuário dominado por maré: Estuário de Caravelas (BA). Rev. Bras. Geof., v. 28, n. 3, p. 427-444, 2010.

RAMOS, A. M.; SANTOS, L. A. R.; FORTES, L. T. G. Normais Climatólogicas do Brasil 1961-1990. Brasilia: Instituto Nacional de Meteorologia, 2009. 465 p.
SCHETTINI, C. A. F. Near bed sediment transport in the ItajaíAçu River estuary, southern Brazil. In: WINTERWERP, J. C; KRANENBURG, C (Eds.). Fine sediment dynamics in the marine environment. New York: Elsevier, 2002b. p. 499-512.

SCHETTINI, C. A. F.; RICKLEFS, K.; TRUCCOLO, E. C.; GOLBIG, V. Synoptic hydrography of a highly stratified estuary. Ocean Dynam., v. 56, n. 3-4, p. 308, 2006.

SCHETTINI, C. A. F.; MIRANDA, L. B. Circulation and suspended particulate matter transport in a tidally dominated estuary: caravelas estuary, Bahia, Brazil. Braz. J. Oceanogr., v. 58 , n. 1, p. 1-11, 2010a.

SCHETTINI, C. A. F.; ALMEIDA, D. C.; SIEGLE, E.; ALENCAR, A. C. B. A snapshot of suspended sediment and fluid mud occurrence in a mixed-energy embayment, Tijucas Bay, Brazil. Geo-Mar. Lett., v. 30, n. 1, p. 47-62, 2010 b.

SCHETTINI, C. A. F.; PEREIRA, M. D.; SIEGLE, E.; MIRANDA, L. B.; SILVA, M. P. Residual fluxes of suspended sediment in a tidally dominated tropical estuary. Cont. Shelf Res., v. 70, p. 27-35, 2013.

SCHUBEL, J. R.; CARTER, H. H. The estuary as a filter for finegrained suspended sediment. In: KENNEDY, V. S. (Ed.). The estuary as a filter. New York: Academic Press, 1984. p. 81105.

SIEGLE, E.; SCHETTINI, C. A. F.; KLEIN, A. H. F.; TOLDO JR, E. E. Hydrodynamics and suspended sediment transport in the Camboriú estuary - Brazil: pre jetty conditions. Braz. J. Oceanogr., v. 57, n. 2, p. 123-135, 2009.

SILVA, D. F.; SOUZA, F. A. S.; KAYANO, M. T. Escalas temporais da variabilidade pluviométrica na bacia hidrográfica do Rio Mundaú. Rev. Bras. Meteorol., v. 25, n. 3, p. 324-332, 2010.

SOUZA, A. C. F. F.; VIEIRA, D. M.; TEIXEIRA, S. F. Conhecimento tradicional dos pescadores de moluscos na Bacia do Pina, Recife-PE. In: Anais do VIII Congresso de Ecologia do Brasil. Caxambu, 2007.

SRH-PE. Secretaria de Recursos Hídricos do Estado de Pernambuco. Plano hidroambiental da bacia hidrográfica do Rio Capibaribe: Tomo I - diagnóstico hidroambiental. Recife: SRH-PE - Projetos Técnicos, 2010. 389 p.

STRETTA, E. Position du Rio Capibaribe Dans L'emsemble Hydrogéologique Du Bassin de Recife. Trab. Instit. Biol. Mar. Oceanogr. Univ. Recife, v. 1, n. 1, p. 71-76, 1959.

TRAVASSOS, P. E. P. F.; MACÊDO, S. J.; KOENING, M. L. Aspectos hidrológicos do estuário do rio Capibaribe (Recife, PE). Trab. Oceanogr. Univ. Fed. Pernamb., v. 22, p. 9-38, 1993.

VALLE-LEVINSON, A.; SCHETTINI, C.A.F. Fortnightly switching of residual flow drivers in a tropical semiarid estuary. Estuarine Coastal and Shelf Science v. 169, p. 4655,2016

WINTERWERP, J. C.; VAN KESTEREN, W. G. M. Introduction to the physics of cohesive sediment dynamics in the marine environment. New York: Elsevier, 2004. 576 p.

ZALESKI, A. R.; SCHETTINI, C. A. F. Procedimentos para Calibração de Perfiladores Acústicos de Corrente por efeito Doppler para a Determinação da Concentração de Material Particulado em Suspensão na Água. Rev. Bras. Rec. Hídric., v. 11, n. 3, p. 191-200, 2006. 
